\title{
A Cyber Age Privacy Doctrine: A Liberal Communitarian Approach
}

\author{
AMITAI ETZIONI*
}

A privacy doctrine built for the cyber age must address a radical change in the type and scale of violations that the nation-and the world-face, namely that the greatest current threats to privacy come not at the point that personal information is collected, but rather from the secondary uses of such information. Often cited court cases, such as Katz, Berger, Smith, Karo, Knotts, Kyllo-and most recently Jones-concern whether or not the initial collection of information was in compliance with the Constitution. They do not address the fact that personal information that was legally obtained may nevertheless be used later to violate privacy-that the ways such information is stored, collated with other pieces of information, analyzed, and distributed or accessed-often entails very significant violations of privacy. ${ }^{1}$ Moreover, although a considerable number of laws and court cases cover these secondary usages of information, they do not come together to make a coherent doctrine of privacy-and most assuredly not one that addresses the unique challenges of the cyber age. ${ }^{2}$

\footnotetext{
* University Professor and Professor of International Affairs at The George Washington University. I previously served as a Senior Advisor at the Carter White House; taught at Columbia University, Harvard, and the University of California at Berkeley; and served as the President of the American Sociological Association. I am the author of numerous books, including The Limits of Privacy and, most recently, Hot Spots. I am indebted to Ashley McKinless for extensive research assistance on this article, and to Alex Platt, Steven Bellovin, Shaun Spencer, and Marc Blitz for comments on a previous draft.

1 Amitai Etzioni, The Privacy Merchants: What Is To Be Done?, 14 PENN. J. CONST. L. 929 (Mar. 2012).

2 Peter P. Swire, Katz is Dead. Long Live Katz, 102 MICH. L. REv. 904, 912 (2002) ("[t]he increasing storage of telephone calls is part of the much broader expansion since 1967 of stored records in the hands of third parties. Although there are no Supreme Court cases on most of these categories of stored records, the Miller and Smith line of cases make it quite
} 
True, collected personal information was subject to secondary abuses even when it was largely paperbound (e.g., in police blotters or FBI files). Indeed, when Warren and Brandeis published their groundbreaking 1890 article in the Harvard Law Review, considered the "genesis of the right of privacy," they were not concerned about gossip per se (a first order privacy violation) but about the wider distribution of intimate details through the media (a secondary violation). ${ }^{3}$ However, the digitization of information, the widespread use of the Internet and computers, and the introduction of artificial intelligence systems to analyze vast amounts of data have increased the extent, volume, scope, and kinds of secondary usages by so many orders of magnitude that it is difficult to find a proper expression to capture the import of this transformation. ${ }^{4}$ The main point is not that information can now be processed at a tiny fraction of the cost and incomparably faster speeds than when it was paper bound, which is certainly the case, but that modes of analysis-which divine new personal information out of personal data previously collected-that are common today were simply inconceivable when most personal information was paper bound. 5 Because these observations are critical to all that follows, and because the term "secondary usages" (which implies usages less important than the first or primary ones) is a

possible that the government can take all of these records without navigating Fourth Amendment protections."). Some scholars have suggested that Fourth Amendment restrictions should apply to subsequent use, although the analysis is not sufficiently developed in the courts to constitute a meaningful privacy doctrine. Harold J. Krent, of Diaries and Data Banks: Use Restrictions Under the Fourth Amendment, 74 TEX. L. REV. $49,51$ (1995) (" $\mathrm{i}] \mathrm{f}$ the state can obtain the information only through means constituting a search or seizure, then use restrictions should apply, confining the governmental authorities to uses consistent with the [Fourth] Amendment's reasonableness requirement").

3 Samuel D. Warren and Louis D. Brandeis, The Right of Privacy, 4 HARV. L. REv. 193 (1890).

4 For an excellent overview of how advances in information and communication technologies have rendered obsolete the privacy laws (and the doctrines on which these laws are based) of the 1980 and 1990 see Omer Tene, Privacy: The new generations, 1 INT' DATA PRIVACY L. 15 (2011). For a discussion of how these changes have particularly affected the privacy expectations of the 'Facebook generation' see Mary Graw Leary, Reasonable Expectations of Privacy for Youth in a Digital Age, 80 Miss. L.J. 1033 (2011).

5 This is of course not a terribly new position-legal scholars have been discussing the implications for privacy and the Fourth Amendment of the Internet since its introduction as publically available technology. See LAWRENCE LESSIG, CODE AND OTHER LAWS OF CYBERSPACE 222-23 (1999) and Laurence H. Tribe, The Constitution in Cyberspace, Keynote Address at the First Conference on Computers, Freedom, \& Privacy (Mar. 26, 1991), available at http://www.sjgames.com/SS/tribe.html. 
rather weak one, I employ from here on the term cybernation to refer to information that is digitized, stored, processed, and formatted for mass distribution. Cybernated data can be employed in two distinct ways, and both represent a serious and growing threat to privacy. A discrete piece of personal information, collected at one point in time ("spot" information) may be used for some purpose other than that for which it was originally deemed constitutional, or spot information may be pieced together with other data to generate new information about the person's most inner and intimate life.

The cyber age privacy doctrine must lay down the foundations on which Congress can develop laws and the courts can accumulate cases that will determine not merely what information the government may legally collect-but also what it might do with that data. According to some legal scholars, the D.C. Circuit's decision in Maynard and the concurring opinion by the Supreme Court's justices in Jones provide the building blocks for this new edifice, sometimes referred to as a mosaic theory of the Fourth Amendment, under which "individual actions of law enforcement that are not searches for Fourth Amendment purposes may become searches when taken together en masse." 6 This observation is based on Justice Alito's argument that the GPS tracking of a vehicle on a public highway constituted a search because of the length of time over which the monitoring took place (twenty-eight days). This opens the door to taking into account the volume of information collected, and presumes that, while limited amounts of collection may be permissible, large amounts could constitute a violation of privacy. Jones, however, still only deals with collection. Hence, most of the work of laying down the foundations for the protection of privacy from cybernation remains to be carried out.

This article first suggests that we cannot rely on the privacy expectations of individuals or society-principles introduced in Katzin developing a new privacy doctrine for the cyber age (Part I, A). This article then briefly indicates that a return to the home as the major focus of privacy will not serve either, and that we are to consider privacy as a protective sphere that follows the individual regardless of

\footnotetext{
${ }^{6}$ Erin Smith Dennis, A Mosaic Shield: Maynard, the Fourth Amendment, and Privacy Rights in the Digital Age, 33 CARDOZO L. REV. 737, 738 (2012). See also Orin Kerr, The Mosaic Theory of the Fourth Amendment, 111 MICH. L. REV. 311, 320 (2012) ("[u]nder mosaic theory, searches can be defined collectively as a sequence of discrete steps rather than as individualized steps. Identifying Fourth Amendment search requires analyzing police actions over time as a collective 'mosaic' of surveillance."); Madelaine Virgina Ford, Mosaic Theory and the Fourth Amendment: How Jones Can Save Privacy in the Face of Evolving Technology, 19 AM. U. J. GENDER SOC. POL'Y \& L. 1351, 1353 (2011); Bethany L. Dickman, Untying Knotts: The Application of Mosaic Theory to GPS Surveillance in United States v. Maryland 60 AM. U. L. REv. 731 (2011).
} 
place (Part I, B). This article then introduces a "social policy model" of the Fourth Amendment to move us forward. ${ }^{7}$ Within this model, we shall see that defining what is minimally intrusive becomes a key issue; instead of treating intrusiveness as a discrete variable, we find it must be treated as a continuous one. That is, the intrusiveness of an act may be considered higher or lower rather than either minimal or not (Part I, C).

Having cleared the way through these deliberations, this article outlines the three dimensions of a cyber age privacy cube: volume, sensitivity, and cybernation (Part II). The last section of this article deals with the issue of defining when the collection and cybernation of information along these dimensions violates privacy (Part III).

\section{PART I. ASSUMPTIONS}

\section{A. Moving Beyond Katz}

Since 1967, the U.S. legal system has drawn on the twin concepts of personal and societal expectations of privacy to determine whether a Fourth Amendment "search" has taken place. This article assumes that relying on both or either expectations of privacy, as articulated by Justice Harlan in his concurring opinion in $\mathrm{Katz}$, is indefensible and that it should be allowed to fade from legal practice. Indeed, Justice Harlan himself adopted rather quickly a critical view of his twopronged test. Four years after Katz, in his dissent for U.S. v. White, Harlan wrote, "[w]hile these formulations represent an advance over the unsophisticated trespass analysis of the common law, they too have their limitations and can, ultimately, lead to the substitution of words for analysis. The analysis must, in my view, transcend the search for subjective expectations." 8

The reasonable expectation of privacy standard has since faced a range of strong criticisms. ${ }^{9}$ In his widely cited article on the Fourth Amendment, Anthony G. Amsterdam writes:

7 Orin S. Kerr, Four Models of Fourth Amendment Protection, 60 STAN. L. REV. 503, 519 (2007).

${ }^{8}$ U.S. v. White, 401 U.S. 745, 786 (1971).

9 Shaun B. Spencer, Reasonable Expectations and the Erosion of Privacy, 39 SAN DIEGO L. REV. 843 (2002); Jim Harper, Reforming the Fourth Amendment Privacy Doctrine, 57 AM. U. L. REV. 5 (2008); Haley Plourde-Cole, Back to Katz: Reasonable Expectation of Privacy in the Facebook Age, 38 FoRDHAM URB. L.J. 571 (2010); Christopher Slobogin \& Joseph E. Schumacher, Reasonable Expectations of Privacy and Autonomy in Fourth Amendment Cases: An Empirical Look at Understandings Recognized and Permitted by Society, 42 DukE L.J. 727 (1993); Richard G. Wilkins, Defining The 'Reasonable 
An actual, subjective expectation of privacy obviously has no place in a statement of what Katz held or in a theory of what the fourth amendment protects. It can neither add to, nor can its absence detract from, an individual's claim to fourth amendment protection. If it could, the government could diminish each person's subjective expectations of privacy merely by announcing half-hourly on television that 1984 was being advanced by a decade and that we were all forthwith being placed under comprehensive electronic surveillance .. . . Fortunately, neither Katz nor the fourth amendment asks what we expect of government. They tell us what we should demand of government. ${ }^{10}$

A leading scholar of the Fourth Amendment and privacy, Orin Kerr, concedes, "[w] hat counts as a 'reasonable expectation of privacy' is very much up for grabs," 11 and much respected students of privacy Charles Whitebread and Christopher Slobogin charge that the Supreme Court has sent "mixed signals" on how to apply this standard. ${ }^{12}$

The absurdity of Katz is revealed by contemplating the following example: Assume a municipal government announces that, for public health reasons, anyone who relieves themselves in a public pool would be charged with a misdemeanor. This government would then insert a dye (which unfortunately only exists in Hollywood's fertile imagination) that would form a dark blue cloud around anyone who violates the ordinance, but would not announce the introduction of this dye. By Katz, surely a person could argue that their expectation of privacy has been grossly violated, as they did not expect to be detected when peeing in the pool. Would it be therefore reasonable to rule this ordinance unconstitutional and to dismiss the charges against them?

Expectation Of Privacy': An Emerging Tripartite Analysis, 40 VAND. L. REV. 1077, 1108 (1987); Sherry F. Colb, What Is A Search? Two Conceptual Flaws In Fourth Amendment Doctrine And Some Hints Of A Remedy, 55 STAN. L. REV. 119, 122 (2002); Silas Wasserstom \& Louis Michael Seidman, The Fourth Amendment as Constitutional Theory, 77 GEO. L.J. 19 (1988).

${ }^{10}$ Anthony G. Amsterdam, Perspectives on the Fourth Amendment, 58 MinN. L. REV. 349, 383 (1974).

11 Orin S. Kerr, The Fourth Amendment and New Technologies: Constitutional Myths and the Case for Caution, 102 MICH. L. REV. 801, 808 (2004).

12 Charles H. Whitebread \& Christopher Slobogin, Criminal Procedure: An Analysis of CASES AND CONCEPTS 116 (3d ed. 1993). 
And once the introduction of the dye is made public, how many people would have to know about it before it is no longer reasonable to expect privacy in the matter? And who determines what is a reasonable expectation, and how? Would one announcement about the new dye suffice, or must it be regularly advertised?

Or, take those who speak in a sizeable political meeting. They may well have no expectation of privacy. However, surely they should be protected from government surveillance in such a setting under most circumstances, to protect their privacy (among other reasons). ${ }^{13}$ And do new technologies change what is expected, with, say, Facebook lowering the standards of privacy because so many people post so much private information? The Electronic Communications Privacy Act (ECPA) only protects emails for ninety days, during which time a warrant is needed for the government to read them. After that, a subpoena from any prosecutor will do, without judicial oversight, because in 1986 the thought of keeping emails around that long was ridiculous because the cost of storing them was so high. Does anyone expect that their emails are private (to the extent that they are) for ninety days but not for more?

As to the societal expectation of privacy, a sociologist is keen to know which, if any, communities will be polled to establish what this expectation is. ${ }^{14}$ Is it the privacy expected by the community of which the defendant is a member-say Spanish Harlem? Or is it the city of New York, or the United States, or the judge's country club? The fact that judges are free to assume they can rely on their sociological instincts as to what the community expects seems a strange foundation to rely on to determine when a search violates the Constitution..$^{15}$

\footnotetext{
13 Further, what is considered a reasonable expectation is in constant flux due to technological changes. Thus, as the use of the Internet for personal communications grew, the Electronic Communications Privacy Act of 1986 failed to protect stored private emails because it was passed in a time when most emails were related to business records, which are expected to be afforded a lesser degree of privacy. See Deirdre L. Mulligan, Reasonable Expectations in Electronic Communications: A Critical Perspective on the Electronic Communications Privacy Act, 72 GEO. WASH. L. REV. 1557 (2004).

${ }_{14}$ Slobogin and Schumacher, supra note 9, at 732 ("a sense of how [innocent] U.S. citizens gauge the impact of police investigative techniques on their privacy and autonomy is highly relevant to current Fourth Amendment jurisprudence. This article describes an effort to obtain some preliminary data in this regard.").

15 RoBERT M. BloOM, SEARCHES, SEIZURES, AND WARRANTS 46 (2003) ("Ib]ecause there is no straightforward answer to this question, 'reasonable' has largely come to mean what a majority of the Supreme Court Justices say is reasonable").
} 
Finally, the whole notion is circular. Mr. Katz-and all otherseither has or does not have an expectation of privacy depending on what the Supreme Court rules. Jim Harper put it well when he wrote: "Societal expectations are guided by judicial rulings, which are supposedly guided by societal expectations, which in turn are guided by judicial rulings, and so on." 16

Four years after the Supreme Court ruled that the police had violated Katz's Fourth Amendment rights by bugging a public pay phone without a warrant, the Court held in United States $v$. White that no warrant was needed to record a conversation in a private home! ${ }^{17} \mathrm{~A}$ reasonable person would expect that Mr. White has a higher expectation of privacy in his home than Mr. Katz has in a public phone booth. Nor is there any reason to believe that "society" found the government's surveillance to be more reasonable in White's home then in the public booth.

Particularly relevant to what follows is that various court cases that draw on Katz seem not to recognize what might be called a "split condition"-that is, situations in which the government collects information in a way that would be considered constitutional because it was "expected," but then uses and distributes it in "unexpected" ways, which would, thus, be in violation of the Constitution. There are, of course, many such split situations, and these situations should be covered by any comprehensive theory of privacy.

In short, it is difficult for a reasonable person to make sense out of Katz. Court rulings on whether a collection of personal information is a "search" by Justice Harlan's formula seem to be highly dependent on what judges think a person or "society" would expect without determining in any half-objective way what these expectations actually are. And, at the same time, such standards ignore that rulings on privacy recast these expectations. It may take a long time before Katz is repealed. Meanwhile more reasonable criteria for privacy need to be developed and used to in effect replace Katz.

\footnotetext{
16 Jim Harper, Reforming Fourth Amendment Privacy Doctrines, 57 AM. U. L. REV.1381, 1392 (2008); See also JEFFrey ROSEN, THE UnWANTED GAZE: THE DESTRUCTION OF PRIVACY IN AMERICA 60 (2001) ("Harlan's test wasapplauded as a victory for privacy, but it soon became clear that it was entirely circular"); Michael Abramowics, Constitutional Cicularity, 49 UCLA L. REV. 1, 60-61 ("Fourth Amendment doctrine, moreover, is circular, for someone can have a reasonable expectation of privacy in an area if and only if the Court has held that a search in that area would be unreasonable").
}

${ }_{17}$ A. Morgan Cloud, Rube Goldberg Meets the Constitution: The Supreme Court, Technology and the Fourth Amendment, 72 Miss L..J. 5 (2002). 


\section{B. But Not Back to 'The Castle'}

To suggest that the time has come to leave behind the reasonable of privacy expectation standard, this is not to say that the courts should revert to pre-Katz Fourth Amendment analysis, which gave considerable weight to the home as the locus of privacy. In Katz the majority ruled "the Fourth Amendment protects people, not places," rejecting the "trespass" doctrine enunciated in Olmstead. ${ }^{18}$ However, even after this, the home remained largely inviolable in the eyes of the courts. It seems Katz did not detach Fourth Amendment safeguards from the home but rather extended the sphere of privacy beyond it to other protected spaces. Information collected about events in one's home is still often considered a priori a violation of privacy, while much more license is granted to the state in collecting information about conduct in public and commercial spaces. As Justice Scalia put it, "'[a]t the very core' of the Fourth Amendment 'stands the right of a man to retreat into his own home and there be free from unreasonable governmental intrusion.' With few exceptions, the question whether a warrantless search of a home is reasonable and hence constitutional must be answered no." ${ }^{19}$ This is an idea that has deep roots in American and English common law: "Zealous and frequent repetition of the adage that a 'man's house is his castle,' made it abundantly clear that both in England and the Colonies 'the freedom of one's house' was one of the most vital elements of English liberty." ${ }^{20}$ In Dow Chemical Company v. United States, the Court established that the expectation of privacy was lower in an industrial plant than a home because the latter "is fundamentally a sanctuary, where personal concepts of self and family are forged, where relationships are nurtured and where people normally feel free to express themselves in intimate ways." ${ }^{21}$

Feminist scholars correctly roundly criticized the inviolability of the home and the private/public distinction in privacy law. Catharine MacKinnon writes the problem with granting the home extra protection is that "while the private has been a refuge for some, it has

\footnotetext{
${ }^{18} \mathrm{Id}$. at 20 (discussing Olmstead v. United States, 277 U.S. 438 (1928)).

19 Kyllo v. United States, 533 U.S. 27, 31 (2001) (quoting Silverman v. United States, 365

U.S. 505, 511 (1961)).

20 Payton v. New York, 445 U.S. 573, 591-98 (1980).

${ }^{21} 749$ F.2d 307, 314 (6th Cir. 1984), affd, 476 U.S. 227 (1986).
} 
been a hellhole for others, often at the same time."22 Linda McClain points out that freedom from state interference in the home "renders men unaccountable for what is done in private-rape, battery, and other exploitation." 23

Moreover, this article draws on the findings that the private/public distinction is rapidly declining in importance in general $^{24}$ and with regard to privacy in particular. ${ }^{25}$ Marc Jonathon Blitz made the case compelling with regard to the cyber age and hence is quoted here at some length:

The 1969 case Stanley $v$. Georgia forbade the government from restricting the books that an individual may read or the films he may watch "in the privacy of his own home." Since that time, the Supreme Court has repeatedly emphasized that Stanley's protection applies solely within the physical boundaries of the home: While obscene books or films are protected inside of the home, they are not protected en route to it-whether in a package sent by mail, in a suitcase one is carrying to one's house, or in a stream of data obtained through the Internet.

However adequate this narrow reading of Stanley may have been in the four decades since the case was decided, it is ill-suited to the twenty-first century, where the in-home cultural life protected by the Court in Stanley inevitably spills over into, or connects with, electronic realms beyond it. Individuals increasingly watch films not, as the defendant in Stanley did, by bringing an eight millimeter film or other physical copy

\footnotetext{
22 Catharine A. MacKinnon, Reflections on Sex Equality Under Law, 100 YALE L.J. 1281, 1311 (1991).

${ }_{23}$ Linda C. McClain, Inviolability and Privacy: The Castle, the Sanctuary, and the Body, 7 YALE J.L. \& HUMAN. 195, 209 (1995).

${ }^{24}$ Amitai Etzioni, The Bankruptcy of Liberalism and Conservatism, 128 PSQ 39 (2013).

${ }_{25}$ Christopher Slobogin, Public Privacy: Camera Surveillance of Public Places And The Right to Anonymity, 72 Miss. L.J. 213 (2002). Scott E. Sundby, Everyman's Fourth Amendment: Privacy or Mutual Trust between Government and Citizen?, 94 ColuM. L. REV. 1751, 1758-59 (Oct. 1994), Bethany L. Dickman, Untying Knotts: The Application of Mosaic Theory to GPS Surveillance in United States v. Maryland 60 AM. U. L. REV. 731 (2011).
} 
of the film into their house, but by streaming it through the Internet. Especially as eReaders, such as the Kindle, and tablets, such as the iPad, proliferate, individuals read books by downloading digital copies of them. They store their own artistic and written work not in a desk drawer or in a safe, but in the "cloud" of data storage offered to them on far-away servers. ${ }^{26}$

Privacy, it follows, is hence best viewed as a personal sphere that follows an individual irrespective of location. This is a version of what Christopher Slobogin refers to as the protection-of-personhood theory of privacy, which "views the right to privacy as a means of ensuring individuals are free to define themselves." 27 Privacy plays the same role whether one is in the home or out in public: "Because a substantial part of our personality is developed in public venues, through rituals of our daily lives that occur outside the home and outside the family, cameras that stultify public conduct can stifle personality development." 28 If the government uses a long distance "shotgun mic" to eavesdrop on the conversations of two persons walking in a public park, such a search is clearly more intrusive than if the government measured the heat setting in their kitchen. This is the case because conversations are much more revealing about the person, including their medical condition, political views, and so on, than their preferred heat setting. ${ }^{29}$ In short, privacy is best not home bound but person centered.

\section{A 'Social Policy' Model of the Fourth Amendment}

The cyber age privacy doctrine concerns the normative principles that underlie both the evolving interpretations of the Constitution and the laws enacted by Congress, reflecting changes in the moral culture of the society. It hence deals both with the Fourth Amendment and public policy. Such normative comprehensive changes have occurred in other areas. For instance, the civil rights movement has led to changes in the position of the Supreme Court (e.g., from Plessy $v$.

\footnotetext{
${ }^{26}$ Marc Jonathan Blitz, Stanley in Cyberspace: Why the Privacy Protection of the First Amendment Should Be More Like That of the Fourth, 62 HASTINGS L.J. 357 (2010).

27 Slobogin, supra note 25 , at 254 .

28 Id. at 255 .

${ }_{29}$ I discuss below the question of whether information that reveals that one is committing a crime deserves extra protection. See infra, Part II.A.
} 
Ferguson to Brown $v$. Board of Education) and-to acts of Congress (e.g., the Voting Rights Act of 1965). More recently, changes were introduced both by the courts and by various legislatures reflecting changes in the characterization of same sex marriage in the moral culture. Now such a change is called for with regard to the concept of privacy. This article next discusses the normative principles of such a reconstituted concept.

(i) In seeking to base a privacy doctrine neither on expectations of privacy nor on location, this article draws on a liberal communitarian philosophy that assumes that individual rights, such as the right to privacy, must be balanced with concerns for the common good, such as those about public health and national security. ${ }^{30}$ (By contrast, authoritarian and East Asian communitarians tend to be exclusively concerned with the common good or pay mind to rights only to the extent that they serve the rulers' aims. ${ }^{31}$ At the opposite end of the spectrum, libertarians and several contemporary liberals privilege individual rights and autonomy over societal formulations of the common good.) Although the term "common good" is not one often found in legal literature, its referent is rather close to what is meant by "public interest," which courts frequently recognize, and a similar concept is found in the U.S. Constitution's reference to the quest for a "more perfect union."

The Fourth Amendment reads: "The right of the people to be secure in their persons, houses, papers, and effects, against unreasonable searches and seizures, shall not be violated." 32 This is a prime example of a liberal communitarian text because it does not employ the absolute, rights-focused language of many other amendments (e.g., "Congress shall make no law"), but recognizes on the face of it that there are reasonable searches, understood as those in which a compelling public interest takes precedence over personal privacy.

(ii) This article assumes that the communitarian balance is metastable. That is, for societies to maintain a sound communitarian regime-a careful balance between individual rights and the common good-societies must constantly adjust their public policies and laws in response to changing external circumstances (e.g., 9/11) and internal developments (e.g., FBI overreach). Moreover, given that societal steering mechanisms are rather loose, societies tend to oversteer and must correct their corrections with still further adjustments.

\footnotetext{
$3^{\circ}$ Amitai Etzioni, Community, ENCYCLOPEDIA OF POLITICAL THOUGHT (forthcoming 2015).

${ }^{31} I d$.

32 U.S. CONST. amend. IV (emphasis added).
} 
For example, in the mid-1970s, the Church and Pike Committees investigated abuses by the CIA, FBI and NSA, uncovering "domestic spying on Americans, harassment and disruption of targeted individuals and groups, assassination plots targeting foreign leaders, infiltration, and manipulation of media and business." 33 As a result, Congress passed the Foreign Intelligence Surveillance Act of 1978 (FISA) and created the Foreign Intelligence Surveillance Court to limit the surveillance of American citizens by the U.S. government. ${ }^{34}$ After 9/11, several reports concluded that the reforms had gone too far by blocking the type of interagency intelligence sharing that could have forestalled the terrorist attacks. 35 As a result, the Patriot Act was enacted in a great rush and, according to its critics, sacrificed privacy excessively in order to enhance security and "correct" what are considered the excesses of the reforms the Church and Pike committees set into motion. Since then, the Patriot Act itself has been recalibrated. ${ }^{36}$

At each point in time, one must hence ask whether society is tilting too far in one direction or the other. Civil libertarians tend to hold that rights in general and privacy in particular are not adequately protected. The government tends to hold that national security and public safety require additional limitations on privacy. It is the mission of legal scholars, public intellectuals, and concerned citizens to nurture dialogues that help sort out in which direction corrections must next be made. ${ }^{37}$ Note that often some tightening in one area

\footnotetext{
33 Post-Watergate Intelligence Investigations, MARY FERRELL FOUNDATION, http://www.maryferrell.org/wiki/index.php/Post-Watergate_Intelligence_Investigations (last visited Mar. 13, 2014).

$34 I d$.

35 Thomas B. Hunter, The Challenges of Intelligence Sharing, OPERATIONAL STUDIES 3 (Dec. 2004).

${ }^{36}$ For a critical analysis of the "Information Sharing Paradigm" that has arisen in law enforcement and intelligence community since 9/11, see Peter P. Swire, Privacy and Information Sharing in the War on Terrorism, 51 VIL. L. REV. 951 (2006).

37 Alexander Aleinikoff, writing in 1987, argued that the courts had entered the "age of balancing." "Balancing has been a vehicle primarily for weakening earlier categorical doctrines restricting governmental power to search and seize." T. Alexander Aleinikoff, Constitutional Law in the Age of Balancing, 96 YALE L.J. 943, 965 (1987). Many civil libertarians have argued that post- $9 / 11$, Fourth Amendment rights are being systematically eroded in the name of national security. See Jay Stanley, Reviving the Fourth Amendment and American Privacy, ACLU (May 28, 2010), http://www.aclu.org/blog/nationalsecurity-technology-and-liberty/reviving-fourth-amendment-and-american-privacy. See also Orin S. Kerr, An Equilibrium-Adjustment Theory of the Fourth Amendment, 125 HARV. L. REV. 476, 478 (2011) ("[t] $]$ he theory of equilibrium-adjustment posits that the Supreme Court adjusts the scope of Fourth Amendment protection in response to new facts
} 
ought to be combined with some easing in others. For instance, currently a case can be made that Transportation Security Administration (TSA) screening regulations are too tight, while the monitoring of whether visitors and temporary residents committed to leaving the U.S. actually do so is too loose.

Orin Kerr and Peter Swire engage in an important dialogue on whether the issues presented above are best suited for treatment by the courts or by Congress, and whether they are largely viewed through the prism of the Fourth Amendment or congressional acts. The following discussion treats both as if they were an amalgam.

(iii) Four criteria help specify the liberal communitarian approach to privacy. ${ }^{38}$ First, a liberal democratic government will limit privacy only if it faces a well documented and large-scale threat to the common good (such as to public safety or public health), not merely a hypothetical threat or one limited to few individuals or localities (I avoid the term "clear and present danger," despite the similarity in meaning, because it has a specific legal reference not here intended). The main reason this threshold must be cleared is because modifying legal precepts-and with them the ethical, social, public philosophies that underlie them-endangers their legitimacy. Changes, therefore, should not be undertaken unless there is strong evidence that either the common good or privacy has been significantly undermined.

Second, if the finding is that the common good needs shoring up, one had best seek to establish whether this goal can be achieved without introducing new limits on privacy. For instance, this is achieved by removing personally identifying information (such as names, addresses and social security numbers) when medical records are needed by researchers, thus allowing access to data previously not accessible. True, various technical difficulties arise in securing the anonymity of the data. Several ingenious suggestions have been made to cope with this challenge. ${ }^{39}$ Conversely, if privacy needs shoring up, one should look for ways to proceed that impose no "losses" to the common good, such as introducing audit trails.

Third, to the extent that privacy-curbing measures must be introduced, they should be as_unintrusive as possible. For example, many agree that drug tests should be conducted on those directly

in order to restore the status quo level of protection. When changing technology or social practice expands government power, the Supreme Court tightens Fourth Amendment protection; when it threatens government power, the Supreme Court loosens constitutional protection.).

${ }^{8}$ See Amitai Etzioni, The Limits of Privacy, 5 (1999).

${ }_{39}$ See infra note 78. 
responsible for the lives of others, such as school bus drivers. Some employers, however, resort to highly intrusive visual surveillance to ensure that the sample is taken from the person who delivers it. Instead, one can rely on the much less intrusive procedure of measuring the temperature of the sample immediately following delivery.

Fourth, measures that ameliorate the undesirable side effects of necessary privacy-diminishing measures are to be preferred over those that ignore these effects. Thus, if contact tracing is deemed necessary to curb the spread of infectious diseases to protect public health, efforts must be made to protect the anonymity of those involved. A third party may inform those who were in contact with an affected individual about such exposure and the therapeutic and protective measures they ought to next undertake, without disclosing the identity of the diagnosed person.

The combined application of these four balancing criteria helps to determine which correctives to a society's course are both needed and not excessive. This article focuses on the third criteria and seeks to address the question: What is least intrusive?

\section{PART II. PRIVACY AS A THREE DIMENSIONAL CUBE}

In this section I attempt to show that to maintain privacy in the cyber age, boundaries on information that may be used by the government should be considered along three major dimensions: The level of sensitivity of the information, the volume of information collected, and the extent of cybernation. These considerations guide one to find the lowest level of intrusiveness holding constant the level of common good. A society ought to tolerate more intrusiveness if there are valid reasons to hold that the threat to the public has significantly increased (e.g., there is an outbreak of a pandemic), and reassert a lower level of intrusiveness when such a threat has subsided.

\section{A. Sensitivity}

One dimension is the level of sensitivity of the information. ${ }^{40}$ For instance, data about a person's medical condition is considered highly sensitive, as is information about one's political beliefs and conduct

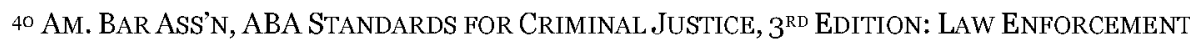
ACCESS TO THIRD PARTY RECORDS STANDARDS (2013), available at http://www.americanbar.org/content/dam/aba/publications/criminal_justice_standards /third_party_access.authcheckdam.pdf.
} 
(e.g., voting) and personal thoughts. Financial information is ranked as less sensitive than medical information, with publically presented information (e.g., license plates) and routine consumer choices even less so.

These rankings are not based on "expectations of privacy" or on what this or that judge divines as societal expectations. ${ }^{11}$ Rather, they reflect shared social values and are the product of politics in the good sense of the term, of liberal democratic processes, and of moral dialogues. ${ }^{42}$ Different nations may rank differently what they consider sensitive. For example, France strongly restricts the collection of information by the government about race, ethnicity, and religion (although its rationale is not the protection of privacy but rather a strong assimilationist policy and separation of the state and church). For those who analyze the law in terms of the law and economics paradigm, disclosure of sensitive data causes more harm to the person by objective standards than does the disclosure of data that is not sensitive. Thus, disclosure of one's medical condition may lead one to lose one's job or not be hired, to be unable obtain a loan, or to incur higher insurance costs, among other harms. By contrast, disclosure of the kinds of bread, cheese, or sheets one buys may affect mainly the kind and amount of spam one receives.

A re-examination of Kyllo helps highlight this principle. If one goes by Katz, the legality of a thermal imaging search from outside the home depends on what one presumes personal and societal expectations to be. At least in middle class American suburbs, people may consider such a heat reading a violation of their expectations. If one clings to the idea that "my home is my castle," measuring the heat inside the home is indeed a major violation of privacy. However, if one goes by the cyber age privacy doctrine here outlined, such readings rank very low on sensitivity because they reveal very little or nothing about the resident's medical, financial, or political preferences, let alone their thoughts. And they detect an extremely low bandwidth of information. The information revealed is less consequential than what kind of cereal or which brand of coffee the person purchased. In

\footnotetext{
${ }^{41}$ Shaun Spencer raises concerns around legislating privacy protections. See Spencer, supra note 9, at 860 (" $[\mathrm{g}]$ iven the powerful influence of various lobbies opposed to strong privacy protection, that role may best be described as a sine qua non. That is, unless the public has a strong desire for privacy in a particular area, attempts to pass legislation establishing that area as a private sphere are doomed to fail ... To the extent that legislatures base privacy legislation on social values and norms, they necessarily rely on the same changing expectations as the judicial conception of privacy").
}

42 AMITAI ETZIONI, FROM EMPIRE TO COMMUNITY: A NEW APPROACH TO INTERNATIONAL RELATIONS 67-71 (2004). 
contrast, taping a person's phone calls is much more revealing. Hence both Kyllo and White deserve to be reversed.

One may argue that information about the heat inside a home is actually particularly sensitive because it reveals that a crime is being committed. Preventing crime is obviously a contribution to the common good. And given that in 2011 fewer than half of violent crimes and twenty percent of property crimes in the U.S. were resolved, some may well hold that public authorities are not excessively indulged when dealing with crime. 43 As to harm to the rights of the individuals involved, they would be harmed only if they had a right to commit a crime. As to the presumption of innocence, there is the public safety exception. The arguments against the notion that crime committed in a home (e.g., spousal abuse) deserves more protection than one committed in public were already presented above. What is new here is that historically, when the Constitution was written, searching a home required a person to enter or peep, which would entail a high level of intrusiveness because the intruder could not but note other potentially sensitive information besides whether or not a crime was being committed. However, technologies that have a very narrow and crime-specific bandwidth (e.g., dogs that sniff for bombs or sensors that measure abnormal levels of heat) and are, hence, very lowly intrusive should be allowed. One may disagree with this line of analysis but still accept the basic point that the lessintrusive collection of insensitive information should be tolerated, while the collection of highly sensitive information should be banned under most circumstances.

Many court cases treat the voluntary release of information to others (and by them to still others, discussed below under the third party doctrine) as if the information disclosed-including phone numbers dialed, 44 copies of written checks, 45 documents given to an accountant, 46 newspaper records, 47 and even papers held by a defendant's attorney ${ }^{48}$-all had the same level of sensitivity. ${ }^{49}$ A

\footnotetext{
43 Federal Bureau of InVESTigation, Uniform Crime RePort: CRIME IN THE United STATES 20112 (Oct. 2012).

44 Smith v. Maryland, 442 U.S. 735, 745 (1979).

45 United States v. Miller, 425 U.S. 435 (1976).

${ }^{46}$ Couch v. United States, 409 U.S. 322 (1973).

47 Zurcher v. Stanford Daily, 436 U.S. 547 (1978).

${ }^{48}$ Fisher v. United States, 425 U.S. 391 (1976).

49 The preceding examples are laid out in Swire, supra note 2, at 908-09.
} 
privacy doctrine that follows the principles here outlined would grant persons more say about the cybernization of sensitive information, while recognizing that the less sensitive information may be used and passed on without the individual's explicit consent.

Over the years, Congress has pieced together privacy law by addressing the protection of one kind of sensitive information at a time, rather than treating all kinds in a comprehensive fashion. Thus, in 1973, the Department of Health, Education and Welfare developed the Code of Fair Information Practices to govern the collection and use of information by the federal government. The principles of the code were incorporated in the Privacy Act of 1974, which "prohibits unauthorized disclosures of the records [the federal government] protects. It also gives individuals the right to review records about themselves, to find out if these records have been disclosed, and to request corrections or amendments of these records, unless the records are legally exempt." 50 The Privacy Act applies only to the federal government and has not been expanded to include records kept by the private sector. In 1986, the ECPA restricted wiretapping, regulated government access to electronic communication stored by third parties, and prohibited the collection of communications content (i.e., what was said, but not who was called) by pen registers. After the Supreme Court ruled in the 1976 case United States $v$. Miller that there was no reasonable expectation of privacy for records at financial institutions, Congress passed the Right to Financial Privacy Act, ${ }^{1}$ which extended Fourth Amendment protections to these records. As required by the 1996 Health Insurance Portability and Accountability Act (HIPAA), in 2002 the Department of Health and Human Services published the final form of "the Privacy Rule," which set the "standards for the electronic exchange, privacy and security of health information." ${ }^{2}$ This accumulation of privacy protections includes laws covering specific sectors-or responding to specific events-but did not provide an overarching design. A well-known case in point is Congress' enactment of the Video Privacy Protection Act after the

\footnotetext{
5o Privacy and Internet, DIPLO,

http://textus.diplomacy.edu/portals/PrivacyAndInternet/oview.asp?FilterTopic=/46434/ 46464\&ShowBlog=false (last visited Apr. 7, 2013).

51 The Right to Financial Privacy Act of 1978, 12 U.S.C. $\S \S 3401-3402$ (2011).

52 Summary of the HIPAA Privacy Rule, DePaRTMENT OF HEAlth AND Human SERVICES, http://www.hhs.gov/ocr/privacy/hipaa/understanding/summary (last visited Mar. 4, 2014).
} 
video rental records of Supreme Court nominee Judge Robert Bork were obtained by a Washington, D.C. newspaper. 53

Congress could help to establish a privacy doctrine for the cyber age by reviewing what by now has been fairly called an incomplete "patchwork of federal laws and regulations" and providing a comprehensive overall ranking of protections based on the sensitivity of the data. ${ }^{54}$ However, many of the building blocks needed for such an edifice are already in place. To develop sensitivity as a criteria for a privacy doctrine does not require a major leap.

\section{B. Volume}

The second dimension on which a cyber age privacy doctrine should draw is the volume of information collected. Volume refers to the total amount of information collected about the same person holding constant the level of sensitivity. Volume reflects the extent of time surveillance is applied (the issue raised in Jones), the amount of information collected at each point in time (e.g., only emails sent to a specific person or all emails stored on a hard drive), and the bandwidth of information collected at any one point in time (e.g., only the addresses of email sent or also their content). A single piece of low-sensitivity data deserves the least protection, and a high volume of sensitive information should receive the most protection.

Under such a cyber age privacy doctrine, different surveillance and search technologies differ in their intrusiveness. Least intrusive are those that collect only discrete pieces of information of the least sensitive kind. These include speed detection cameras, tollbooths, and screening gates, because they all reveal, basically, one piece of information of relatively low sensitivity. Radiation detectors, heat reading devices and bomb and drug-sniffing dogs belong in this category, not only because of the kind of information (i.e., low or not sensitive) they collect, but also because the bandwidth of the information they collect is very low (i.e., just one facet, indeed a very narrow one, and for a short duration).

Typical closed-circuit televisions (CCTVs)-privately owned, mounted on one's business, parking lot, or residential lobby-belong in the middle range because they pick up several facets (e.g., location, physical appearance, who one associates with), but do so for only a brief period of time and in one locality. The opposite holds for

\footnotetext{
53 The Video Privacy Protection Act of 1988,18 U.S.C. $\S 2710$ (2013).

54 Gina Stevens, Cong. Research Serv., R41756, Privacy Protections for Personal INFORMATION ONLINE (2011), available at http://www.fas.org/sgp/crs/misc/R41756.pdf.
} 
Microsoft's Domain Awareness System, first tested in New York City in 2012. The program collates thousands of pieces of information about the same person from public sources-such as that from the city's numerous CCTV cameras, arrest records, 911 calls, license plate readers, and radiation detectors-and makes them easily and instantly accessible to the police. While the system does not yet utilize facial recognition, it could be readily expanded to include such technology.

Phone tapping-especially if not minimized and continued for extended period of time-and computer searches, collect considerable volume. (This should not be conflated with considerations that come under the third dimension: Whether these facts are stored, collated, analyzed and distributed i.e., the elements of cybernation). Drones are particularly intrusive because they involve much greater bandwidth and have the potential to engage in very prolonged surveillance at relatively low costs compared to, say, a stake out. These volume rankings must be adapted as technologies change. The extent to which combining technologies is intrusive depends on the volume (duration and bandwidth, holding sensitivity constant) of information collected. High volume searches should be much more circumscribed than low volume ones.

When the issue of extending privacy protection beyond spot collection arose in Jones, several legal scholars, in particular Orin Kerr, pointed to the difficulties of determining when the volume of collection was reasonable and when it became excessively intrusive. Kerr writes:

In Jones, the GPS device was installed for 28 days. Justice Alito stated that this was 'surely' long enough to create a mosaic. But he provided no reason why, and he recognized that 'other cases may present more difficult questions.' They may indeed. If 28 days is too far, how about 21 days, or 14 days, or 3.6 days? Where is the line?55

In response, one notes that there are many such cut off points in law, such as the number of days suspects may be detained before they must be charged or released, the voting and driving ages, the number of jurors necessary for due process, and so on. One may say that they reflect what a "reasonable" person would rule. Actually, they reflect what judges consider a compromise between a restriction that is clearly excessive and one that's clearly inadequate-a line that has

55 Kerr, supra note 6, at 333 . 
been adjusted often. There is no reason the volume of collection should not be similarly governed.

\section{Cybernation: Storing, Analysis, and Access}

The third dimension is the one that is increasing in importance and regarding which law and legal theory have the most catching up to do. To return to the opening deliberations of this article, historically, much attention was paid to the question of whether the government can legally collect certain kinds of information under specific conditions. This was reasonable because most violations of privacy occurred through search and surveillance that implicated this firstlevel collection, that of spot information. True, some significant violations also occurred in the paper age as a result of collating information, storing it, analyzing it, and distributing it. However, to reiterate, as long as records were paper bound, which practically all were, these secondary violations of privacy were inherently limited when compared to those enabled by the digitization of data and the use of computers (i.e., by cybernation).

To illustrate the scope and effects of cybernation a comparison follows: In one state, a car passes through a tollbooth, a picture of its license plate (but not the driver or others on the front seat) is takenand then this information is immediately deleted from the computer if the proper payment has been made. In another state, the same information, augmented with a photo of the passengers, is automatically transmitted to a central data bank. There, it is combined with many thousands of other pieces of information about the same person, from locations they have visited (e.g. based on cell tower triangulation) to their magazine subscriptions and recent purchases and so on. The information is regularly analyzed by artificial intelligence systems to determine if people are engaged in any unusual behavior, what places of worship they frequent (e.g. flagging Mosques), which political events they attend (e.g. flagging those who are who participated in protests), and if they stop at gun shows and so on and on. The findings are widely distributed to local police and the intelligence community and can be gained by the press and divorce lawyers.

Both systems are based on the same spot information, that is, pieces of information pertaining to a very limited, specific event or point in time-as in the case in the first state. However, if such information is combined with other information, analyzed, and distributed, as depicted in the second scenario, it provides a very comprehensive and revealing profile of one's personal life. In short, the most serious violations of privacy are often perpetuated not by surveillance or information collection per se, but by combination, 
manipulation, and data sharing-by cybernation. The more information is cybernated, the more intrusive it becomes.

\section{PART III. LIMITING INTRUSION BY CYBERNATION}

There are in place two major systematic approaches to dealing with privacy violations that result from secondary uses: The third party doctrine and the EU Data Protection Directive (DPD). The third party doctrine holds that once a person voluntarily discloses a fact to another party, that party is free (unless explicitly banned) to pass on (or sell) this information to third parties, and those various third parties are free to further process this information, collate it with other data, draw inferences, and so on-in short, to cybernate it. $5^{6}$

This approach is challenged by critics who note that in the cyber age much of our private lives are lived in a cyber world operated by third parties like Google and Facebook. Thus, Matthew Lawless writes:

The third party doctrine gives effect to the criticism often aimed at the 'reasonable expectation of privacy' principle, by holding that individuals can only reasonably expect privacy where the Court gives them that privacy. Because the third party doctrine fails to address true societal expectations of privacy (as evident by its failure to protect any information entered into a search engine), it reinforces the privacy norms of a politically and temporally insulated judiciary: [O]nce people know their searches are exposed, then-by the time these cases are contested-there will, in truth, be no expectation of privacy. ${ }^{5} 7$

However, even without drawing on whatever the societal expectation of privacy is, one notes that considerable harm will come to people and that core societal values will be violated if the third

\footnotetext{
${ }^{56}$ Information voluntarily handed over to another party does not receive Fourth Amendment protection "even if the information is revealed on the assumption that it will be used only for a limited purpose and the confidence placed in the third party will not be betrayed." United States v. Miller, 425 U.S. 435, 443 (1976); see also Orin Kerr, The Case for the Third Party Doctrine, 107 MICH. L. REV. 561, 569-70 (2009). Earlier cases that built up this doctrine include Couch v. United States, 409 U.S. 322 (1973); Lee v. United States, 343 U.S. 747 (1952).

57 Matthew D. Lawless, The Third Party Doctrine Redux: Internet Search Records and the Case for a "Crazy Quilt" of Fourth Amendment Protection, 2 UCLA.J.L. \& TECH. 1 (2007).
} 
party doctrine is given free rein. This observation is strengthened by the fact that various exceptions to the third party doctrine are already in place, such as special rules for medical and financial information. However, according to Greg Nojeim, these rules do not provide the same level of protection granted by the Fourth Amendment. He notes that "privacy statutes that protect some categories of sensitive personal information generally do not require warrants for law enforcement access." 58 Furthermore, Matthew Tokson argues that "the conflation of disclosure to automated Internet systems with disclosure to human beings" has led the court to exclude from Fourth Amendment protection a great deal of personal information, including "Internet protocol (IP) addresses, e-mail to/from information, information about the volume of data transmitted to a user, name, address, and credit card information, and even the contents of a user's e-mails." 59 In short, the third party doctrine provides very little privacy protection and the less so the more cybernation is developed and extended.

The European Union's DPD in effect takes the opposite view, namely, that any secondary use of personal information released by a person or collected about him requires the explicit a priori approval of the original individual "owner" of the information, and that this consent cannot be delegated to an agent or machine. ${ }^{60}$ The details of DPD are complex and changing. ${ }^{61}$ For instance, it made exceptions from this rule for many areas, such as when the data is needed for the purposes of research, public health, or law enforcement, among others. In January 2012, the European Commission passed draft legislation that would update the existing data protection law. This legislation includes an "opt in" provision: "As a general rule, any processing of personal data will require providing clear and simple information to concerned individuals as well as obtaining specific and

\footnotetext{
${ }_{58}$ Orin Kerr and Greg Nojeim, The Data Question: Should the Third-Party Records Doctrine Be Revisited?, ABA J. (Aug. 1, 2012), available at http://www.abajournal.com/magazine/article/the_data_question_should_the_thirdparty_records_doctrine_be_revisited.

59 Matthew Tokson, Automation and the Fourth Amendment, 96 IowA L. REV. 581,586 (2011).

6o Daniel Cooper, Consent in EU Data Protection Law, EURoPEAN PRIVACY ASSOCIATION, http://www.europeanprivacyassociation.eu/public/download/EPA\%2oEditorial_\%20Con sent\%20in\%20EU\%20Data\%2oProtection\%2OLaw.pdf (last visited Mar. 13, 2014).

61 Why Do We Need an EU Data Protection Reform?, EUROPEAN COMMISSION, http://ec.europa.eu/justice/data-protection/document/review2012/factsheets/1_en.pdf (last visited Mar. 13, 2014).
} 
explicit consent by such individuals for the processing of their data." Data show that information about a person is used many times each day by a large variety of users. Hence, if such a policy were systematically enforced, each Internet user would have to respond to scores if not hundreds of requests per day even for uses of nonsensitive information. It seems that in this area, as in many others, the way DPD rules survive is by very often not enforcing them. Whenever I meet Europeans, and following public lectures in the EU, I ask if anyone has been ever asked to consent to the use of personal information that they had previously released. I have found only one person so far. He said that he got one such request-from Amazon. Other sources indicate that compliance is at best "erratic."62 The penalties for violating the DPD seem to be miniscule and rarely collected. No wonder a large majority of the EU public-seventy percent-fear that their personal data may be misused. ${ }^{63}$ In short, neither of these approaches is satisfactory.

In addition, there are in place a large number of laws, regulations, and guidelines that deal with limited particular usages of personal information beyond the collection point. However, a very large number of them deal with only one dimension of the cube and often with only one element of cybernation, limiting either storage, or analysis, or distribution. The laws reflect the helter-skelter way they were introduced and do not provide a systematic doctrine of cyber privacy. They are best viewed as building blocks, which, if subjected to considerable legal scholarship and legislation, could provide the needed doctrine. They are like a score of characters in search of an author.

One of the key principles for such a doctrine is that the legal system can be more tolerant of the primary point spot collection of personal information (a) the more limited the volume (duration and bandwidth) of the collection ${ }^{64}$ and (b) the more limited and regulated

\footnotetext{
62 Erica Newland, CDT Comments on EU Data Protection Directive, CENTER FOR DEMOCRACY AND TECHNOLOGY (Jan. 20, 2011), https://www.cdt.org/blogs/ericanewland/cdt-comments-eu-data-protection-directive.

${ }^{63}$ Data Protection Reform: Frequently Asked Questions, EuRoPa (Jan. 25, 2012), http://europa.eu/rapid/press-release_MEMO-12-41_en.htm?locale=fr.

64 In the wake of Jones, Professor Susan Freiwald identified four factors that the courts use to extend Fourth Amendment protection to new surveillance technologies that "make sense." These include whether the target is unaware of the surveillance; it covers items that the people consider private; it is continuous; and it is indiscriminate (covers more information than is necessary for establishing guilt). Susan Freiwald, The Four Factor Test, THE SELECTED WORKS OF SUSAN FREIWALD (2013), available at http://works.bepress.com/susan_freiwald/11.
} 
cybernation is-holding constant the level of sensitivity of the information. That is, much more latitude can be granted to the collection and cybernation of insensitive information, stricter limitations can be placed on highly sensitive information, and a middle level of protection can be established in between.

In other words, a cyber age privacy doctrine can be much more tolerant of primary collection conducted within a system of laws and regulations that are effectively enforced to ensure that cybernation is limited, properly supervised, and employed for legitimate purposes and much less so, if the opposite holds. One may refer to this rule as the positive correlation between the level of permissiveness in primary collection and the strictness of controls on secondary usage of personal information.

Another key principle is a ban on using insensitive information to divine the sensitive (e.g., using information about routine consumer purchases to divine one's medical condition) because it is just as intrusive as collecting and employing sensitive information. ${ }^{65}$ This is essential because currently such behavior is rather common. ${ }^{66}$ Thus, under the suggested law, Target would be prevented from sending coupons for baby items to a teenage girl after the chain store's analysis of her recent purchases suggest she might be pregnant. ${ }^{67}$ And surely Target would be prevented from selling this information to call comers. To further advance the cyber age privacy doctrine, much more

\footnotetext{
65 People often trust assurances that their sensitive information (names and social security number) can be deleted when their data is collected in large databases. In fact, scientists have shown that individuals can be easily "deanonymized." Paul Ohm writes that this misunderstanding has given the public a false sense of security and has lead to inadequate privacy protections, laws and regulations. See Paul Ohm, Broken Promises of Privacy: Responding to the Surprising Failure of Anonymization, 57 UCLA L. REV. 1701 (2010). See also Marcia Stepanek, Weblining, Bus. WK. (Apr. 3, 2000), available at http://www.businessweek.com/200o/oo_14/b3675027.htm; Jennifer Golbeck, Christina Robles \& Karen Turner, Predicting Personality with Social Media, CHI EXTENDED ABSTRACTS 2011, 253-262.

${ }^{66}$ Marcy Peek, Passing Beyond Identity on the Internet: Espionage and Counterespionage in the Internet Age, 28 VT. L. REv. 91, 94 (2003) (evaluating ways to resist discriminatory marketing in cyberspace); Stepanek, supra note 65 ([a] data broker company Acxiom matches names against housing, education, and incomes in order to identify the unpublicized ethnicity of an individual or group); Nicholas Carr, Tracking Is an Assault on Liberty, With Real Dangers, WALL ST. J. (Aug. 6, 2010), http://online.wsj.com/news/articles/SB1000142405274870374890457541168271438988 8 ("[i]t used to be ... you had to get a warrant to monitor a person or a group of people. Today, it is increasingly easy to monitor ideas"); Etzioni, supra note 1, at 948-50.
}

${ }^{67}$ How Target Figured Out a Teen Girl Was Pregnant Before Her Father Did, FoRBES (Feb. 16, 2012), available at http://www.forbes.com/sites/kashmirhill/2012/o2/16/howtarget-figured-out-a-teen-girl-was-pregnant-before-her-father-did. 
attention needs to be paid to private actors. Privacy rights, like others, are basically held against the government, to protect people from undue intrusion by public authorities. However, increasingly cybernation is carried out by the private sector. There are corporations that make shadowing Internet users-and keeping very detailed dossiers on them-their main line of business. According to Slobogin:

Companies like Acxiom, Docussearch, ChoicePoint, and Oracle can provide the inquirer with a wide array of data about any of us, including: Basic demographic information, income, net worth, real property holdings, social security number, current and previous addresses, phone numbers and fax numbers, names of neighbors, driver records, license plate and VIN numbers, bankruptcy and debtor filings, employment, business and criminal records, bank account balances and activity, stock purchases, and credit card activity. ${ }^{68}$

And these data are routinely made available to the government, including the FBI. Unless this private cybernation is covered, the cyber age privacy doctrine will be woefully incomplete. ${ }^{69}$

Given that private actors are very actively engaged in cybernation and often tailor their work so that it might be used by the government (even if no contract is in place and they are, hence, not subject to the limits imposed on the government), extending the privacy doctrine beyond the public/private divide is of pivotal importance for the future of privacy in the cyber age. Admittedly, applying to the private sector similar restrictions and regulations that control the government may well be politically unfeasible in the current environment. However, as one who analyzes the conditions of society from a normative viewpoint, I am duty bound to point out that it makes ever less sense to maintain this distinction. ${ }^{\circ}$ Privacy will be increasingly lost in the cyber age, with little or no gain to the common good, unless private actors-and not just the government-are more reined in. To what extent this may be achieved by self-regulation, changes in norms, increased transparency, or government regulation is a question not here addressed.

68 Christopher Slobogin, Government Data Mining and the Fourth Amendment, 75 U. CHI. L. REV. 317, 320 (2008).

69 For further discussion on these matters see Etzioni, supra note 1; Etzioni, supra note 24 (discussing the collapse of the public-private divide).

70 For more discussion see Etzioni, supra note 24. 
For this doctrine to be further developed, laws and court rulings ought to be three-dimensional. ${ }^{71}$ These laws and court cases had best specify not only whether a particular collection of personal information is a "search," but also what level of sensitivity can be tolerated and to what extent the information may be stored, analyzed, and distributed. This may seem-and is-a tall, if not impossible, order. However, as is next illustrated, a considerable number of measures are already in place that are, in effect, at least twodimensional. These, though, suffer from the fact that they have been introduced each on their own and do not reflect an overarching doctrine of privacy; hence, they reveal great inconsistencies that need to be remedied. I cannot stress enough that the following are but selective examples of such measures.

One should note that a very early attempt to deal with the issuebasically, in terms here used, by banning a form of cybernationutterly failed. In 2003, Congress shut down the Pentagon's Total Information Awareness (TIA) program, which was created to detect potential terrorists by using data mining technologies to analyze unprecedented amounts of personal transaction data. However, a report by the Wall Street Journal in 2008 revealed that the most important components of TIA were simply "shifted to the NSA" and "put in the so-called black budget, where it would receive less scrutiny and bolster other data-sifting efforts." 72

Minimization is one way of addressing the volume issue, as Swire pointed out in his groundbreaking article on Jones and the mosaic theory. ${ }^{73}$ Accordingly, when the FBI taps a phone, even for an extended period of time, the intrusion can be reduced significantly if the FBI either stops listening when it hears that the conversation is not relevant to the investigation (e.g., a child is calling the suspect under surveillance) or locks away those segments of the taped correspondence that turn out to be irrelevant. ${ }^{74}$ For this rule to be

\footnotetext{
${ }^{71}$ Kerr sees a greater role here for Congress, while Swire sees a greater role for the courts. See Swire, supra note 2, at 912; Kerr, supra note 11. This article is unable to add to these deliberations other than to recognize that both are needed and neither seems able to keep up with changing technologies.

${ }^{72}$ Siobhan Gorman, NSA's Domestic Spying Grows As Agency Sweeps Up Data, WALL ST. J., Mar. 10, 2008, available at http://online.wsj.com/news/articles/SB120511973377523845.

73 Peter P. Swire, A Reasonableness Approach to Searches After the Jones GPS Tracking Case, 64 STAN. L. REV. ONLINE 57 (2012).

${ }^{74}$ Gary T. Marx, Ethics for the New Surveillance, 14 INFO. Soc'Y: AN INT'L J. 171, 178 (1998).
} 
integrated into the doctrine, it may be waived for insensitive information. That is, there would be no need to minimize if the child asked, say, to watch TV, but activated if she asked, say, about medical news concerning a family member.

Another example of a safeguard against excessive privacy intrusions is the requirement that certain content be deleted after a specific time period. Most private companies that utilize CCTV erase video footage after a set number of days, such as after a week. Admittedly, their reasons for doing so may be simply economic; however, the effect is still to limit the volume of collection and potential for subsequent abuse. Note that that there are no legal requirements to erase these tapes. However, such laws ought to be considered (Europeans are increasingly recognizing a "right to be forgotten"). It would be in the public interest to require that footage be kept for a fixed period of time (as it has proven useful in fighting crime and terrorism), but also ban under most circumstances the integration of the video feed into encompassing and cybernated systems of the kind Microsoft has developed.

The treatment of private local CCTVs should be examined in the context of the ways other such spot collection information is treated. Because the bandwidth of information collected by toll booths, speed cameras and radiation detectors is very narrow, one might be permitted to store it longer and feed it into cybernated systems. By contrast, cell phone tracking can be utilized to collect a great volume and bandwidth of information about a person's location and activities. People carry their phones to many places they cannot take their cars, where no video cameras or radiation detectors will be found, including sensitive places such as political meetings, houses of worship, and residences. These rules must be constantly updated as what various technologies can observe and retain constantly changes.

Regulations to keep information paper bound have been introduced for reasons other than protecting privacy, but these requirements still have the effect of limiting intrusiveness. For example, Congress prevents the Bureau of Alcohol, Tobacco, Firearms and Explosives (ATF) from computerizing gun records when such information is collected during background checks. ${ }^{75}$ In 2013, an amendment to the anti-insider trading STOCK Act exempted 28,000 executive branch staff from having to post their financial disclosure

75 Erica Goode and Sheryl Gay Stolberg, Legal Curbs Said to Hamper A.T.F. in Gun Inquiries, N.Y.TIMES, Dec. 25, 2012, available at http://www.nytimes.com/2012/12/26/us/legislative-handcuffs-limit-atfs-ability-to-fightgun-crime.html?pagewanted=all\&_r=o. 
forms "online in a searchable, sortable and downloadable format." 76 These bans remind one that not all the privacy measures that are in place are legitimate and that some are best scaled back rather than enhanced.77

A related issue is raised by the cybernation of arrest records. Arrest records should be but are not considered highly-sensitive information. When these records, especially those concerning people who were subsequently released without any charges, were paper bound, the damage they inflicted on most people's reputations was limited. However, as a result of cybernation, they have become much more problematic. Under the suggested doctrine, arrest records of people not charged after a given period of time would be available only to law enforcement officers. The opposite might be said about data banks that alert the public to physicians that have been denied privileges for cause, a very high threshold that indicates serious ethical shortcomings.

Many computer systems ("clouds" included) encrypt their data and a few have introduced audit trails. The cyber age privacy doctrine might require that all data banks that contain sensitive information be encrypted and include at least some rudimentary form of an audit trail.

Technologies can be recalibrated to collect the "need to know" information while shielding extraneous but highly sensitive information from observation. For example, when law enforcement collects DNA samples from convicted criminals or arrested individuals, FBI analysts create DNA profiles using so-called "junk DNA" "because it is not 'associated with any known physical or medical characteristics,' and thus theoretically poses only a minimal invasion of privacy." 78 Storing these "genetic fingerprints" in national databases is much less intrusive than retaining data produced by blood samples, which "reveal sensitive medical or biological information."79 In 2013, the TSA stopped its use of body scanners that revealed almost-nude images, using instead scanners that produce "cartoon-like" images on which the scanners mark places hidden

${ }^{6}$ Tamara Keith, How Congress Quietly Overhauled Its Insider-Trading Law, NPR(Apr. 16, 2013), http://m.npr.org/news/Politics/177496734.

77 Etzioni, supra note 38.

${ }^{78}$ ANNA C. HENNING, CONG. RESEARCH SERV., R40077, COMPUlSORY DNA ColleCtion: A FOURTH AMENDMENT ANALYSIS 2 (2010) (quoting United States v. Kincade, 379 F.3d 813, 818 ( $9^{\text {th }}$ Cir. 2004) (en banc)).

$79 \mathrm{Id}$. at 13 . 
objects are found. ${ }^{80}$ This did not affect the volume of collection, but lessened the sensitivity of the content.

Other measures must address the fact that often data can be "reidentified" or "de-anonymized." In 2006, AOL released the search records-stripped of "personal identifiers"-of over 600,000 people. An investigation by the New York Times, however, demonstrated that intimate information-including names and faces-could be gleaned from such purportedly anonymous data. This risk is mitigated by the development of statistical methods that prevent such undertakings, such as "differential privacy," which allows curators of large databases to release the results of socially beneficial data analysis without compromising the privacy of the respondents who make up the sample. ${ }^{81}$

Many more examples could be provided. However, the above list may suffice to show that, while there are numerous measures in place that deal with various elements of the privacy cube, these have not been introduced with systematic attention to the guiding principles needed for the cyber age.

\footnotetext{
80 Jack Nicas, TSA to Halt Revealing Body Scans at Airports, WALL ST. J. (Jan. 18, 2013) http://online.wsj.com/news/articles/SB10001424127887323783704578250152613273568.

81 Cynthia Dwork, Differential Privacy: A Survey of Results, TAMC LNCS 4978, 1-19 (2008) available at http://www.cs.ucdavis.edu/ franklin/ecs289/2010/dwork_2008.pdf ([r]oughly speaking, differential privacy ensures that the removal or addition of a single database item does not [substantially] affect the outcome of any analysis. It follows that no risk is incurred by joining the database, providing a mathematically rigorous means of coping with the fact that distributional information may be disclosive").
} 
